0912

\title{
メタンを用いた触媒燃焼装置の開発と製作
}

Development of catalytic combustor using methane gas

○学 岡田 和総（長岡技大院） 正 山岸 郷志（長岡技科大） 正 岡崎 正和（長岡技科大）

Kazufusa OKADA, Graduate Student, Nagaoka university of Technology, Kamitomiokamachi 1603-1, Nagaoka, Niigata

Satoshi YAMAGISHI, Nagaoka university of Technology , Kamitomiokamachi 1603-1, Nagaoka, Niigata

Masakazu OKAZAKI, Nagaoka university of Technology , Kamitomiokamachi 1603-1, Nagaoka, Niigata

Key Words: catalytic combustor, methane

1. はじめに

近年，ごみ処理場から発生するバイオガスなど質の悪い メタンを含むガスをガスタービン発電に利用するニーズが 高まっている。また地震災害により，一般家庭においても 発電機の需要が高まっている. ${ }^{(1)}$ 本研究では, ガスタービ ンの燃焼器のガスの燃焼効果の促進と, ガスタービンを小 型化するためにプラチナ触媒を用いた燃焼器の開発を行っ た。触媒にはペレット状のアルミナを担体とし，プラチナ を担持した方式とし, 独自の設計により燃焼器を製作した. その上で触媒燃焼によるガス, 空気の流量, 比率を変化さ せた時の触媒燃焼器の温度の変化, 排出ガスの変化を実測 しながら, 開発した触媒燃焼器の特性を調査した。

\section{2. 触媒燃焼器について}

2.1 触媒燃焼器の構成

Fig.1 に開発した実験装置の概要を示す. 本研究の実験装 置は, ガス供給系, 流量計, 混合器, 触媒燃焼器, 温度測 定に $\mathrm{K}$ 型熱電対, シース熱電対を使用, 排ガス検出装置か ら成る。燃料にはボンベガスを使用し, 水素, メタン, 空 気を使用する。使用する触媒はプラチナ $(\mathrm{Pt})$ であり, その サポーターとしてペレット状のアルミナを担体とし用いる. 排ガスを水抜き用の冷却ビンを通して質量分析装置にて分 析した。ここで触媒燃焼器の温度は $\mathrm{K}$ 型熱電対で測定し, 排ガス温度はシース熱電対にて測定した. Fig. 2 に試験部と なる触媒燃焼器の構成を示す. 燃焼器はステンレス鋼製で 外観寸法は直径 $34 \mathrm{~m} \mathrm{~m}$, 長さ $50 \mathrm{~m} \mathrm{~m}$ である. CH2〜4 部で は燃焼器表面温度を測定し, $\mathrm{CH} 1$ は排ガス温度を測定して いる。 なお内部の燃焼筒は直径 $12 \mathrm{~mm}$ である。触媒層には プラチナ-アルミナペレット状触媒を充填し, 金網にて支持 した。予混合燃料を供給管から導入し, 燃焼ガスを排気管 にて排出する.

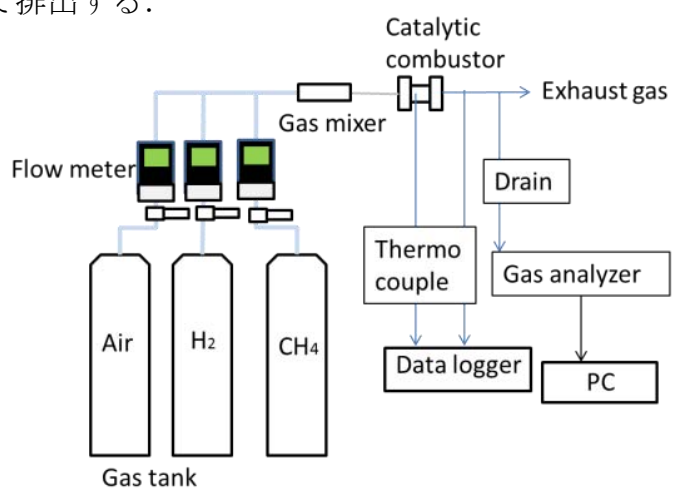

Fig.1 Schematic diagram of Experimental apparatus.

2.2 実験方法

まず，水素 $600 \mathrm{ml} / \mathrm{s}$ と空気 $1.5 \mathrm{~L} / \mathrm{s}$ を触媒燃焼器に流し燃 焼器温度が約 $400^{\circ} \mathrm{C}$ になるまで予熱し, その後, 水素に代 わってメタンを流した。後者のプロセス中は，温度測定と 排ガス成分の分析を行った。ここでメタンを流寸量は以下 の化学式から酸素 $2 \mathrm{~mol}$ に対して $1 \mathrm{~mol}$ のメタンを流すこと とした．これは空気内の酸素を $20 \%$ として考えると，理想

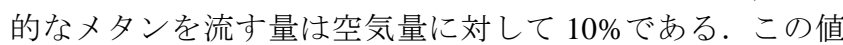

を基準として空気量，メタン量を変えたときの燃焼の状態 を排ガスの温度と排ガス分析を行いながら調査した。

$\mathrm{CH} 4+2 \mathrm{O} 2 \rightarrow \mathrm{CO} 2+2 \mathrm{H} 2 \mathrm{O}$

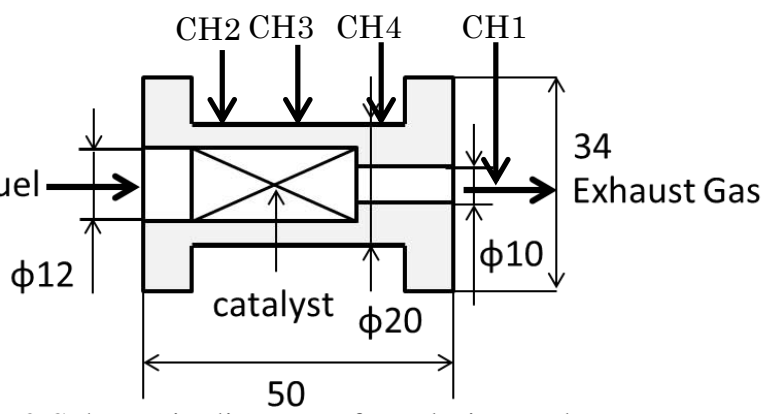

Fig .2 Schematic diagram of catalytic combustor 3 結果と考察

3.1 触媒燃焼器装置の温度や排気ガス特性の観察

Fig.4 は供給ガスの変化と, 標準状態とする空気 $6 \mathrm{~L} / \mathrm{s}$, メ タン $600 \mathrm{ml} / \mathrm{s}$ を流した場合の燃焼器の温度と排ガス成分を 示す. 水素燃焼時は入り口側の $\mathrm{CH} 2$ が一番高く, メタン燃 焼時は燃焼器真ん中 $\mathrm{CH} 3$ の温度が一番高くなることがわ かる. 空気 $6 \mathrm{~L} / \mathrm{s}$, メタン $600 \mathrm{ml} / \mathrm{s}$ とした標準状態に対して, メタンの供給量を 0.8 倍にした場合，失火し，0.9 倍とした 場合には燃焼が行われた。メタン供給量を 1.4 倍とした Fig.5 からはメタンを多く供給した場合水素が然焼しきれ ず多量に出ていることがわかる。これはメタンや触媒に反 応し, 分解された水素が反応しきれずに排出されたものだ と考えられる. Fig.6 は空気量, メタン量をそれぞれ $4 \mathrm{~L} / \mathrm{s}$, $400 \mathrm{ml} / \mathrm{s}$ に減らした図である. Fig.3 と Fig.6を比較すると最 大温度，温度上昇量は変わるのみである。

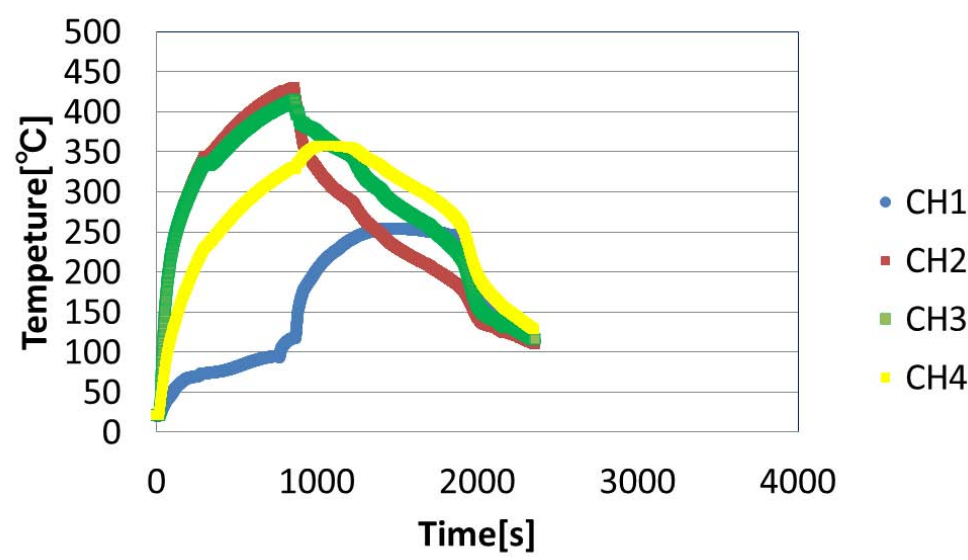

Fig. 3 Combustion temperature of catalytic combustion Air 6L/s methane $480 \mathrm{ml} / \mathrm{s}$ 

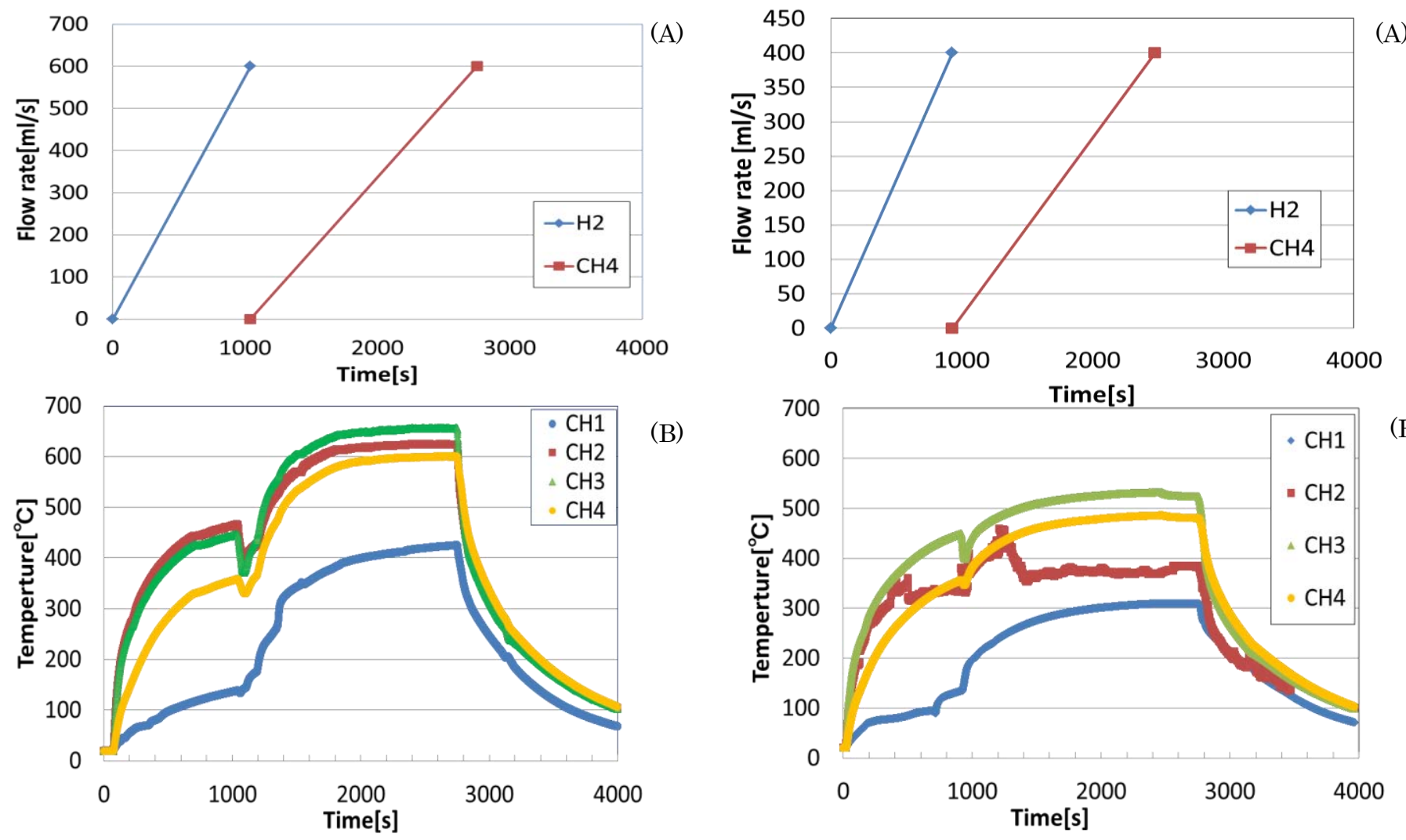

(B)

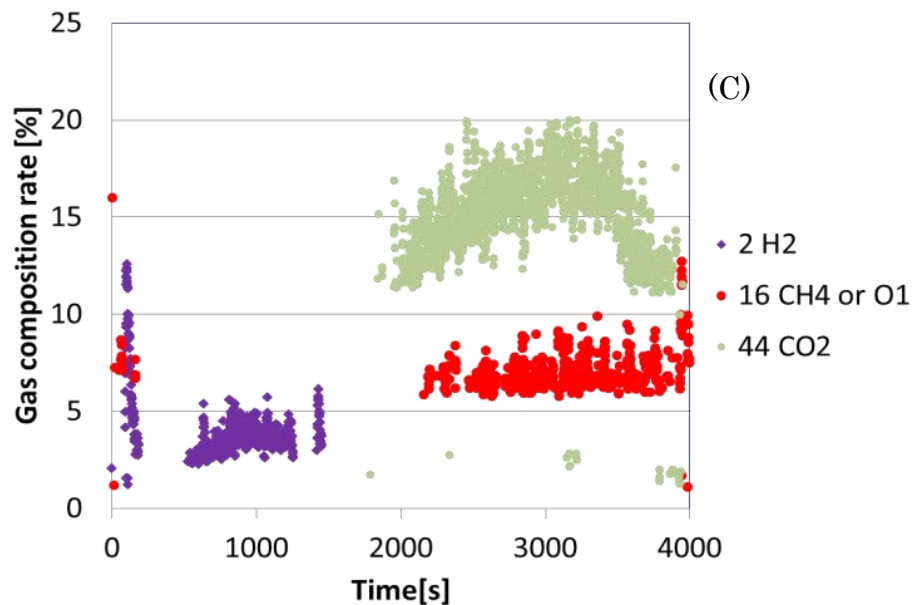

Fig.4 Feed gas(A) and combustion temperature(B) and exhaust gas constituent (C)of catalytic combustion Air 6L/s, methane $600 \mathrm{ml} / \mathrm{s}$

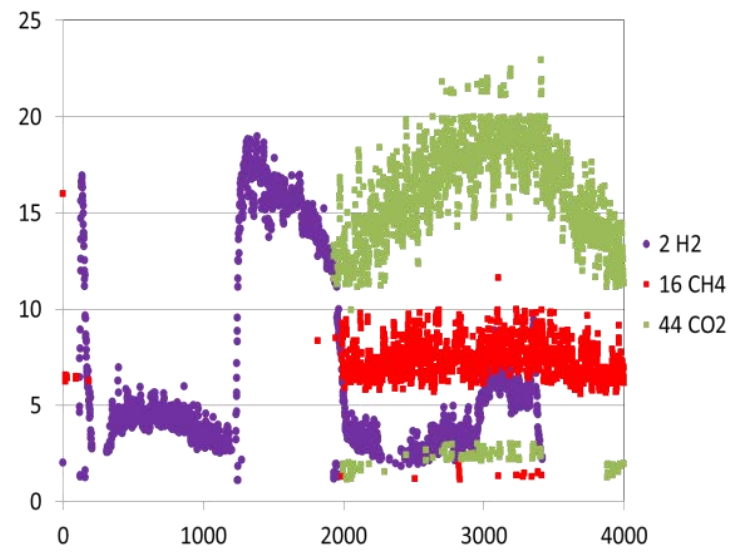

Fig.5 exhaust gas constituent of catalytic combustion Air6L/s methane $840 \mathrm{ml} / \mathrm{s}$ 